\title{
Effects of Different Tillage Methods on the Soil Bulk Density and Growth Parameters of Watermelon (Citrullus lanatus)
}

\author{
Babatunde KM*, Oyedele DJ Shittu KA and Adekanmbi OA \\ ${ }^{1}$ Department of Agricultural Technology, The Oke-Ogun Polytechnic, Saki, Oyo State, Nigeria \\ ${ }^{2}$ Department of Soil Science and Land Resources Management, Obafemi Awolowo University, Ile-Ife, Osun State, Nigeria
}

${ }^{3}$ Department of Agronomy, Osun State University, Ejigbo Campus, Osun State, Nigeria

Received: October 12, 2017; Accepted: November 16, 2017; Published: December 20, 2017

*Corresponding author: Babatunde KM, Department of Agricultural Technology, The Oke-Ogun Polytechnic, Saki, Oyo State, Nigeria, Tel: 08051279769; E-mail: mbabatundekayode@gmail.com

\begin{abstract}
Research was conducted to determine the effects of different tillage methods on the soil bulk density and growth parameters of Watermelon (Citrullus lanatus). The study was carried out at the Vegetable Research Farm, The Oke - Ogun Polytechnic, Saki; with treatments at three levels of tillage (T0- zero tillage, T1- one pass of moldboard plow and T2- two passes of moldboard plow); all treatments replicated three times and arranged in three blocks in a Completely Randomized Block Design (CRBD). Each plot was (1.2 $\mathrm{m} \times 1.2 \mathrm{~m}$ ) with $1 \mathrm{~m}$ and $1.5 \mathrm{~m}$ gap between the plots and blocks. Tillage methods affected the soil bulk density and watermelon growth parameters as shown that one pass of moldboard plow $(1.3 \mathrm{gm} / \mathrm{cm} 3)$ had the greatest mean vine length, stem girth and number of leaves $(5.3 \mathrm{~cm}, 3.1 \mathrm{~cm}$ and 13$)$ respectively. Paired t- minitab 17.0 showed that the zero tillage $(1.6 \mathrm{gm} / \mathrm{cm} 3)$ and one pass of moldboard plow $(1.3 \mathrm{gm} / \mathrm{cm} 3)$ bulk densities are significantly $(\mathrm{p} \leq 0.05)$ different, while two passes of moldboard plow $(1.5 \mathrm{gm} / \mathrm{cm} 3)$ and one pass of moldboard plow $(1.3 \mathrm{gm} / \mathrm{cm} 3)$ are statistically $(\mathrm{p} \leq 0.05)$ the same. The summary of analysis of variance of effects of tillage methods on the watermelon growth parameters, revealed that blocks had no significant $(p \leq 0.05)$ effects on all the growth parameters, while tillage had significant $(\mathrm{p} \leq 0.05)$ effects on the mean vine length, stem girth and leaf area. Least significant $(\mathrm{p} \leq 0.05)$ different therefore, revealed that one pass of moldboard plow $(1.3 \mathrm{gm} / \mathrm{cm} 3)$ significantly $(\mathrm{p} \leq 0.05)$ increased the vine length and stem girth than other tillage methods. The study concluded that for a one pass of moldboard plow $(1.3 \mathrm{gm} /$ $\mathrm{cm} 3$ ) at $11.5 \%$ moisture content; the growth of watermelon could be enhanced on sandy clay soil, in the derived savannah of Southwest zone of Nigeria.
\end{abstract}

Keywords: Moisture content; plow; Cucurbitacea; Vegetable; Derived savanna;

\section{Introduction}

Watermelon (Citrullus lanatusThumb) belongs to the family Cucurbitaceae $[1,2,3]$. Its centre of origin has been traced to both the Kalahari and Sahara deserts in Africa [4] and these areas have been regarded as point of diversification to other parts of the world [1, 2, 3].Sweet, juicy watermelon is actually packed with some of the most important antioxidants in nature. Watermelon is an excellent source of vitamin $\mathrm{C}$ and a very good source of vitamin
A, notably through its concentration of beta-carotene. Pink watermelon is also a source of the potent carotenoid antioxidant, lycopene. These powerful antioxidants move through the body neutralizing free radicals[5]. In Nigeria, though there are no official figures recorded for its production, the crop has a wide distribution as a garden crop, while as a commercial vegetable production; its cultivation is confined to the drier savanna region of the Nigeria [6]. Watermelon (Citrullus lanatus) is a relative of melons (Cucumis melo), cantaloupe, honeydew, crenshaw, winter and summer squash (Cucurbita pepo var. melopepo), pumpkin (Cucurbita pepo var. pepo), and cucumbers (Cucumis sativus). Collectively, known as the cucurbits, Watermelon, Citrullus lanatus, is part of the Cucurbitaceae family which includes squash, pumpkins, cucumbers, muskmelons and gourds; it is a vine-like (scrambler and trailer) flowering plant. Watermelon cultivation in the world; 1.8 million hectare (dry land and irrigated) with production of 29.9 million tons [7]. In Nigeria, this fruit crop is mostly cultivated in the northern part because it is a warmthloving plant and this makes its production seasonal in the southern part of the country [8]. Its global consumption is greater than that of any other cucurbit. According to $[9,10]$, watermelon is the most preferred among five other exotic vegetables (Cucumber, Carrot, Lettuce, Cabbage and Sweet melon) examined in Ibadan Metropolis of Oyo State, Nigeria. Individual plants produce both male and female flowers and fruit size varies from 2 to $14 \mathrm{~kg}$, depending on variety and is thought to have originated in Southern Africa. Today, watermelon is cultivated all over the world on all five continents. Watermelon is frost sensitive and are monoecious (both male and female flowers are produced on the same plant). The flowers remain open for approximately a day and are insect pollinated. Watermelon flowers are yellow, fivepetalled flowers about $1 \mathrm{~cm}$ in diameter (smaller than some of the other vine fruit). Watermelons are usually eaten as fruit, in fruit salads or as deserts. Optimum germination temperature, growth temperatures at night, day and ripening are $27-32{ }^{\circ} \mathrm{C}, 18-20$ ${ }^{\circ} \mathrm{C}, 24-30^{\circ} \mathrm{C}, 15-25^{\circ} \mathrm{C}$ respectively with night temperature not lower than $24^{\circ} \mathrm{C}$. Watermelons can be grown on a wide range of soil types although sandy soils are preferred. The highest yields 
will generally be produced on well-drained sandy loam soil. Heavy clay soils, soils with obstructed drainage, or very shallow soils should be avoided. Soil pH should be about 5.8-6.2 $\left(\mathrm{H}_{2} \mathrm{O}\right)$. It is usually recommended to lime soil with $\mathrm{pH}$ values below 5.5 $\left(\mathrm{H}_{2} \mathrm{O}\right)$.

Soil tillage is one of the cultural practices that affect soil physical properties and yield of crops [11,12].reported that among the crop production factors, tillage contributed up to 20 $\%$. Tillage method affects the sustainable use of soil resources through its influence on soil properties, proper tillage can improve soil related constraints, while improper tillage may cause a range of undesirable processes such as destruction of soil structure, accelerated erosion, depletion of organic matter content and fertility destruction of cycles of water, organic carbon and plant nutrients and encourage excessive weed emergence $[13,14,15]$. The indiscriminate tillage can increased soil erosion, evaporation, decreased permeability, increased runoff and increased soil compaction. In most cases, the performance of crops in conservation plow methods compared with conventional plow methods was similar or was higher [16]. Watermelons grow best on sandy loam soils, with good drainage and a slightly acid $\mathrm{pH}$. When planted in very heavy soils, the plants develop slowly and fruit size and quality are usually inferior. Fine sands produce the highest quality melons when adequate fertilizer and water are provided [17].

The objective of the study was to determine the effects of different tillage methods on the soil bulk density and growth parameters of Watermelon (Citrullus lanatus).

\section{Materials and Method}

\section{Site}

The study was carried out at the Vegetable Research Farm, The Oke - Ogun Polytechnic, Saki; located within latitude 8.33o $\mathrm{N}$ and longitude $3.40 \mathrm{o} \mathrm{E}$ in the derived savannah zone, South western Nigeria, average humidity, temperature and soil moisture of $66 \%, 28$ o C and $9.3 \%$ respectively between 10th June and August, 2017. The pattern of rainfall is bimodal, with the average annual rainfall estimated to be about $1100 \mathrm{~mm}$. (The Oke - Ogun Polytechnic WatchDog weather station). The experiment was sited within 1 hectare Agricultural field that has been previously planted with maize and vegetables.

\section{Treatments}

Research was conducted with treatments at three levels of tillage (T0- zero tillage, T1-one pass of moldboard plow and T2two passes of moldboard plow); all treatments replicated three times and arranged three blocks in a Completely Randomized Block Design (CRBD). Each plot was (1.2 m x $1.2 \mathrm{~m}$ ) with $1 \mathrm{~m}$ and $1.5 \mathrm{~m}$ gap between the plots/replicates and blocks respectively. The no - tilled or zero tillage was done with contact herbicide (Clearweed @ 3 litres/ha for annual grasses + annual broad leaved weeds), hoe and cutlass to clear the land after three (3) days of application of the herbicide. Pre-cropping chemical analysis of the experimental soil was carried out before land preparation (Table 3). Table 2 indicated the tractor and implement specification used for the experiment, (Table 1 )also indicated the composition of the organic fertilizer bought at Agroallied shop, Saki, Oyo State, Nigeria. Canned seeds of watermelon with inscription: Top Harvest; germination/purification 85 /99 $\%$, treated with Biostim protection, was bought at Agro-allied product shop in Saki, Oyo State, Nigeria,two seeds of watermelon were sown perhole with intra and inter row spacing of $1.2 \mathrm{~m} \mathrm{x}$ $1.2 \mathrm{~m}$ and about $2 \mathrm{~cm}$ deep, thinned to one seedling per stand 2 Weeks After Planting (WAP). The fertilizer (250 gm/plot) was applied in two split doses, the first application of organic fertilizer was applied two weeks before planting, and the second dose fertilizer treatments was applied three weeks after planting by side dressing and lightly covered with soil. At four weeks of planting, Kuru (Brand insecticide); Cypermethrin $10 \%$ EC was applied at $650 \mathrm{ml} / \mathrm{ha}$.

Table1: Labeled chemical composition of the synthetic organic fertilizer used

\begin{tabular}{|c|c|}
\hline Composition & $\mathbf{\%}$ \\
\hline Nitrogen & 5 \\
\hline Phosphorous & 2.5 \\
\hline Potassium & 1.5 \\
\hline
\end{tabular}

\section{Soil Analysis and Growth Parameters}

Three core samples were taken randomly at the research locations at depth of $15 \mathrm{~cm}$ with the aid of $5 \mathrm{~cm}$ diameter metal cylinder (core sampler) for routine physical and chemical analysis. The soil samples were air dried, crushed and sieved to pass through $2 \mathrm{~mm}$ sieve, and analyzed. The particle size distribution was carried out using the hydrometer method described by as presented by using $0.2 \mathrm{M}$ sodium hydroxide as dispersing agent $[18,19]$. Undisturbed soil cores were collected by driving with a rubber hammer $5 \mathrm{~cm}$ diameter metal cylinder into the soil to the depth specified for each sample. Bulk densities were calculated based on the volumes, calculated from the length and diameter of the section and dry weights of the soil samples. The soil $\mathrm{pH}$ was determined using a glass electrode $\mathrm{pH}$ meter, that is; soil - water suspension (1:1); organic carbon was determined by the chromic acid digestion method [20]. The total nitrogen concentration was determined by macro-Kjeldahl method and the available $\mathrm{P}$ was extracted by Bray -1 method and determined using spectrometer[21,22]. Exchangeable $\mathrm{K}, \mathrm{Ca}, \mathrm{Na}$, and Mg were extracted with neutral ( $\mathrm{pH} 7$ ) solution of $1 \mathrm{~N} \mathrm{NH4OAc,} \mathrm{K}$ and $\mathrm{Na}$ were determined using the flame photometer and $\mathrm{Mg}$ and Ca by the atomic absorption spectrophotometer. Growth parameters of watermelon were measured from the plots; vine length $(\mathrm{cm})$, stem girth $(\mathrm{cm})$, number of leaves and mean leaf area $(\mathrm{cm} 2)$ at the end of the experiment ( 7 weeks). The taller plant from each plot was selected for vine length measurement which was measured from the soil level to tip of the plant with a meter rule. The leaf area (length $\mathrm{x}$ width) was also measured by the meter rule, leaf length was measured from the lamina tip to the point of intersection of the lamina and petiole and the width measured from tip to tip between the widest lamina lobes. The number of leaves was simply counted, while the stem girth was measured by measuring the stem close to the ground with vernier caliper. 


\section{Statistical Analysis}

Statistical significance of bulk densities generated as a result of different tillage methods was evaluated using Paired $\mathrm{t}$ - samples of Minitab 17.0 statistical software package, while data collected from the field on effects of the tillage methods on the growth parameters of Watermelon (Citrullus lanatus)were subjected to Analysis of Variance (ANOVA) and Least Significant Different (LSD) to seperate the means.

\section{Results and Discussion}

The properties of the soil used for the experiment (Table 3) indicated a sandy clay soil (sand $67 \%$, silt $8 \%$ and clay $25 \%$ ) and $\mathrm{pH}$ of 6.9.The slightly acidity nature of the soil could be as a result of high rainfall in the area which made the soil fragile and susceptible to erosion and leaching [23]. The pH of 6.9, however, was within acceptable range expected for optimum growth of the crop as the pH should not be less than 5.5. The effect of tillage methods (zero - tilled; $1.6 \mathrm{~g} / \mathrm{cm}^{3}$, one pass of moldboard plow; $1.3 \mathrm{~g} / \mathrm{cm}^{3}$ and two passes of moldboard plow; $1.5 \mathrm{~g} /$ $\mathrm{cm}^{3}$ ) (Table $5-8$ ), the zero -tilled bulk density was the highest $\left(1.6 \mathrm{~g} / \mathrm{cm}^{3}\right)$ while the one pass of moldboard plow $(1.3 \mathrm{~g} / \mathrm{cm} 3)$ reduce the bulk density and the bulk density increased at two passes of moldboard plow $\left(1.5 \mathrm{~g} / \mathrm{cm}^{3}\right)$. The soil preferred for watermelon was sandy soil, however, the soil type used for this experiment was sandy clay and this could be the reason for the high bulk densities of the different tillage methods. The statistical significant effects of these bulk densities were tested by paired $\mathrm{t}$ - samples Minitab 17.0 soft ware package; result showed that the zero and one pass of moldboard plow bulk densities are significantly $(p \leq 0.05)$ different, while two passes of moldboard plowand one pass of moldboard plow are statistically ( $p \leq 0.05$ ) the same (Table 4). The tractor and the implements specifications used for this study (Table 2) was not a heavier type according to [24]. Result presented here was also consistent with those obtained by [25] who studied the influence of different tillage systems on bulk density, [26] similarly observed significantly higher bulk density under zero or no tillage cultivation when compared to conventional tillage treatment. This finding was also in agreement with what was reported by $[27,28,29]$.One of the reasons for increasing the soil bulk density in no till system is this system because of non-use of tillage machines will not also cause any upset. These results are therefore, compatible with findings of $[30,31]$.

Table 2: Tractor and implement specification

\begin{tabular}{|c|c|}
\hline Item & Specification \\
\hline \multicolumn{2}{|l|}{ (a) Disc plough } \\
\hline Number & 3 \\
\hline Dimension & $2.2 \mathrm{~m}$ \\
\hline (b) Tractor source of power & Diesel \\
\hline (c) Weight of tractor & 2.4 tons \\
\hline (d) Number of cylinder & 4 \\
\hline (e) Model of tractor & Mahindra 605 D1 \\
\hline (f) Horse power & 65 \\
\hline
\end{tabular}

Table 3: The physical and chemical parameters of the soil used for the experiment

\begin{tabular}{|c|c|}
\hline Parameter & value \\
\hline $\mathrm{PH}\left(\mathrm{H}_{2} \mathrm{O}\right)$ & 6.9 \\
\hline Sand (\%) & 67 \\
\hline Clay (\%) & 25 \\
\hline Silt (\%) & 8 \\
\hline Texture & Sandy clay \\
\hline Moisture content at tillage (\%) & 11.5 \\
\hline \multicolumn{2}{|c|}{ Exchangeable bases (mol/kg) } \\
\hline $\mathrm{Ca}$ & 38 \\
\hline $\mathrm{Mg}$ & 2.4 \\
\hline $\mathrm{Na}$ & 0.1 \\
\hline K & 0.7 \\
\hline $\mathrm{H}+\mathrm{AL}$ & 0.1 \\
\hline Exchangeable CEC (C mol/kg) & 39 \\
\hline$\%$ Base saturation & 65.6 \\
\hline \multicolumn{2}{|c|}{ Micro nutrient (mg/kg) } \\
\hline $\mathrm{C}$ & 4.4 \\
\hline $\mathrm{N}$ & 1 \\
\hline $\mathrm{P}$ & 8 \\
\hline $\mathrm{Cu}$ & 0.6 \\
\hline $\mathrm{Mn}$ & 11 \\
\hline $\mathrm{Fe}$ & 15 \\
\hline $\mathrm{Zn}$ & 2 \\
\hline
\end{tabular}

Table 4:* Paired $t$ - samples Minitab test of effect of different tillage methods on bulk density

\begin{tabular}{|c|c|c|}
\hline Tillage/bulk density & $\mathbf{t}$ - value & P-value \\
\hline aT0 - T1b & 5.2 & $0.04^{*}$ \\
\hline aT0 -T2a & 0 & $1.00 \mathrm{~ns}$ \\
\hline aT1 - T2a & -3.46 & $0.07 \mathrm{~ns}$ \\
\hline
\end{tabular}

The effect of tillage methods (Table 5) indicated that one pass of moldboard plow $\left(1.3 \mathrm{gm} / \mathrm{cm}^{3}\right)$ had the highest mean vine length $(5.3 \mathrm{~cm})$ while the zero tillage $\left(1.6 \mathrm{gm} / \mathrm{cm}^{3}\right)$ had the least $(3.5 \mathrm{~cm})$. Tillage systems affected the water melon stem girth (Table 6) as shown that the one pass of moldboard plow $\left(1.3 \mathrm{gm} / \mathrm{cm}^{3}\right)$ had the greatest girth $(3.1 \mathrm{~cm})$ and the least girth $(1.3 \mathrm{~cm})$ was obtained as a result of zero tilled $\left(1.6 \mathrm{gm} / \mathrm{cm}^{3}\right)$ effect. Table 7 observed the leaf area; which indicated that two passes of moldboard plow $\left(1.5 \mathrm{gm} / \mathrm{cm}^{3}\right)$ had the largest leaf area $\left(30 \mathrm{~cm}^{2}\right)$ and the least $\left(22.8 \mathrm{~cm}^{2}\right)$ was at zero -tilled $\left(1.6 \mathrm{gm} / \mathrm{cm}^{3}\right)$. The highest mean number of leaves (Table 8) was obtained at one pass of moldboard plow $\left(1.3 \mathrm{gm} / \mathrm{cm}^{3}\right)$ plot (13) while zero - tilled $\left(1.6 \mathrm{gm} / \mathrm{cm}^{3}\right)$ plot recorded the least mean number of leaves (9). The summary analysis of variance (Table 9) and LSD (Table 5 - 8) indicated that block significant $(\mathrm{p} \leq 0.05)$ effectwas not observed on all the growth parameters. Tillage methods as treatment however, had significant $(p \leq 0.05)$ effects the vine length, stem girth and 
leaf area except number of leaves where no significant ( $\mathrm{p} \leq 0.05)$ effects of tillage methods was observed. Least significant ( $p \leq$ 0.05 ) different of means effects on the vine length, stem girth and leaf area showed that one pass of moldboard plow $\left(1.3 \mathrm{gm} / \mathrm{cm}^{3}\right)$ and two passes of moldboard plow $\left(1.5 \mathrm{gm} / \mathrm{cm}^{3}\right)$ tillage methods were statistically $(\mathrm{p} \leq 0.05)$ the same, but the zero $\left(1.6 \mathrm{gm} / \mathrm{cm}^{3}\right)$ tillage had negative or reduced significant $(\mathrm{p} \leq 0.05)$ effects on the vine length. The stem girth of watermelon increased significantly $(\mathrm{p} \leq 0.05)$ by the one pass of moldboard plow $\left(1.3 \mathrm{gm} / \mathrm{cm}^{3}\right)$ tillage method, however, the two passes of moldboard plow $1.5 \mathrm{gm} /$ $\left.\mathrm{cm}^{3}\right)$ and zero tillage $\left(1.6 \mathrm{gm} / \mathrm{cm}^{3}\right)$ tillage methods had the same statistical $(p \leq 0.05)$ effects on the stem girth of watermelon. The two passes of moldboard plow $\left(1.5 \mathrm{gm} / \mathrm{cm}^{3}\right)$ and one pass of moldboard plow $\left(1.3 \mathrm{gm} / \mathrm{cm}^{3}\right)$ had the same statistical ( $\left.\mathrm{p} \leq 0.05\right)$ effect on the leaf area, but significantly $(p \leq 0.05)$ different from the zero $\left(1.6 \mathrm{gm} / \mathrm{cm}^{3}\right)$ tillage method.

[32] Generally, the soil type (sandy clay) and the available moisture content (11.5\%) at tillage could have effects on the bulk densities and this consequently, resulted in lowered vine length, number of leaves and significantly $(\mathrm{p} \leq 0.05)$ reduced the stem girth on the two passes of moldboard plow $\left(1.5 \mathrm{gm} / \mathrm{cm}^{3}\right)$ when compared with one pass of moldboard plow $\left(1.3 \mathrm{gm} / \mathrm{cm}^{3}\right)$ tillage method, this assertion was supported by.

[11] opined that tillage methods significantly ( $p \leq 0.05$ ) affected crop yield, fruit weight, fruit length and fruit diameter of watermelon, also supported the assertion that zero tillage had the highest bulk density.

[33] also concluded under Rice-Wheat system, that tillage practices influenced soil physical characteristics and crop productivity.

One of the reasons for the low yield in no-tillage treatments than other treatments can be linked to seed germination under zero tillage with high bulk density, thus contributed to slow and reduced growth of the growth parameters( vine length, stem girth, leaf area and number of leaves). This was also consistent with the findings of $[34,35]$.

Table 5: Effect of different tillage methods on the vine length of water melon $(n=27)$

\begin{tabular}{|l|l|l|l|l|l|}
\hline Blocks & $\begin{array}{l}\text { zero } \\
\text { tillage }\end{array}$ & $\begin{array}{l}\text { one pass } \\
\text { plow }\end{array}$ & $\begin{array}{l}\text { two } \\
\text { passes } \\
\text { plow }\end{array}$ & $\Sigma$ & mean \\
\hline & $1.6 \mathrm{bd}$ & $1.3 \mathrm{bd}$ & $1.5 \mathrm{bd}$ & 14.3 & $4.8 \mathrm{a}$ \\
\hline B1 & 3.5 & 5.5 & 5.3 & 13.5 & $4.5 \mathrm{a}$ \\
\hline B2 & 3.5 & 5.1 & 4.9 & 13.8 & $4.6 \mathrm{a}$ \\
\hline B3 & 3.6 & 5.2 & 5 & & \\
\hline$\sum$ & 10.6 & 15.8 & 15.2 & & \\
\hline mean & $3.5 \mathrm{~b}$ & $5.3 \mathrm{a}$ & $5.1 \mathrm{a}$ & & \\
\hline
\end{tabular}

Table 6: Effect of different tillage methods on the stem girth of water melon $(n=27)$

\begin{tabular}{|l|l|l|l|l|l|}
\hline Blocks & $\begin{array}{l}\text { zero } \\
\text { tillage }\end{array}$ & $\begin{array}{l}\text { one pass } \\
\text { plow }\end{array}$ & $\begin{array}{l}\text { two } \\
\text { passes } \\
\text { plow }\end{array}$ & $\Sigma$ & mean \\
\hline & $1.6 \mathrm{bd}$ & $1.3 \mathrm{bd}$ & $1.5 \mathrm{bd}$ & 5.9 & $2.0 \mathrm{a}$ \\
\hline B1 & 1.2 & 3.2 & 1.5 & 6.6 & $2.2 \mathrm{a}$ \\
\hline B2 & 1.4 & 3 & 2.2 & 6.7 & $2.2 \mathrm{a}$ \\
\hline B3 & 1.3 & 3.1 & 2.3 & & \\
\hline$\sum$ & 3.9 & 9.3 & 6 & & \\
\hline mean & $1.3 \mathrm{~b}$ & $3.1 \mathrm{a}$ & $2 \mathrm{~b}$ & & \\
\hline
\end{tabular}

Table 7: Effect of different tillage methods on the leaf area of water melon ( $n=27)$

\begin{tabular}{|l|l|l|l|l|l|}
\hline Blocks & $\begin{array}{l}\text { zero } \\
\text { tillage }\end{array}$ & $\begin{array}{l}\text { one pass } \\
\text { plow }\end{array}$ & $\begin{array}{l}\text { two } \\
\text { passes } \\
\text { plow }\end{array}$ & $\Sigma$ & mean \\
\hline & $1.6 \mathrm{bd}$ & $1.3 \mathrm{bd}$ & $1.5 \mathrm{bd}$ & 82.8 & $27.6 \mathrm{a}$ \\
\hline B1 & 23.6 & 30.4 & 28.8 & 78.8 & $26.3 \mathrm{a}$ \\
\hline B2 & 21.2 & 27 & 30.6 & 85.5 & $28.5 \mathrm{a}$ \\
\hline B3 & 23.7 & 31.1 & 30.7 & & \\
\hline$\Sigma$ & 68.5 & 88.5 & 90.1 & & \\
\hline mean & $22.8 \mathrm{~b}$ & $29.5 \mathrm{a}$ & $30 \mathrm{a}$ & & \\
\hline
\end{tabular}

Table 8: Effect of different tillage methods on the number of leaves of water melon $(n=27)$

\begin{tabular}{|l|l|l|l|l|l|}
\hline Replicates & $\begin{array}{l}\text { zero } \\
\text { tillage }\end{array}$ & $\begin{array}{l}\text { one } \\
\text { pass } \\
\text { plow }\end{array}$ & $\begin{array}{l}\text { two } \\
\text { passes } \\
\text { plow }\end{array}$ & $\Sigma$ & mean \\
\hline & $1.6 \mathrm{bd}$ & $1.3 \mathrm{bd}$ & $1.5 \mathrm{bd}$ & 35 & $12 \mathrm{a}$ \\
\hline B1 & 10 & 14 & 11 & 31 & $10 \mathrm{a}$ \\
\hline B2 & 8 & 10 & 13 & 34 & $11 \mathrm{a}$ \\
\hline B3 & 9 & 15 & 10 & & \\
\hline$\sum$ & 27 & 39 & 34 & & \\
\hline mean & $9 \mathrm{a}$ & $13 \mathrm{a}$ & $11 \mathrm{a}$ & & \\
\hline
\end{tabular}

\section{Summary and Conclusion}

The effects of tillage methods on the soil bulk density and growth parameters of watermelon at $11.5 \%$ moisture were investigated on a sandy clay soil. Soil dry bulk densities was determined (zero/no - tilled; $1.6 \mathrm{~g} / \mathrm{cm}^{3}$, one pass of moldboard plow; $1.3 \mathrm{~g} / \mathrm{cm}^{3}$ and two passes of moldboard plow; $1.5 \mathrm{~g} / \mathrm{cm} 3$ ) by the core method and indicated that soil physical property (bulk density) and the growth parameters of watermelon were influenced by the tillage methods.

The result indicated that zero tillage method at $1.6 \mathrm{~g} / \mathrm{cm}^{3}$ bulk density significantly ( $\mathrm{p} \leq 0.05)$ reduced the vine length, stem girth, leaf area, but the reduction in the number of leaves was not significant $(\mathrm{p} \leq 0.05)$. The one pass of moldboard plow $(1.3$ $\mathrm{g} / \mathrm{cm} 3)$ tillage method had significant $(\mathrm{p} \leq 0.05)$ effects on the 


\begin{tabular}{|c|c|c|c|c|c|c|c|c|}
\hline \multicolumn{2}{|c|}{ Table 9: Summary of analysis of variance (ANOVA) of effects of different tillage methods on growth parameters of watermelon } \\
\hline Source of variation & \multicolumn{2}{|c|}{ vine length } & \multicolumn{2}{|c|}{ stem girth } & \multicolumn{2}{|c|}{ leaf area } & \multicolumn{2}{c|}{ no. of leaves } \\
\hline & $\mathrm{ms}$ & $\mathrm{fcal}$ & $\mathrm{ms}$ & $\mathrm{fcal}$ & $\mathrm{ms}$ & $\mathrm{fcal}$ & $\mathrm{ms}$ & $\mathrm{fcal}$ \\
\hline Block & 0.05 & $2.5 \mathrm{~ns}$ & 0.06 & 0.86 & 3.79 & $1.82 \mathrm{~ns}$ & 1.44 & $0.32 \mathrm{~ns}$ \\
\hline Tillage & 2.7 & $135^{*}$ & 2.47 & $35.29 *$ & 48.28 & $23.21^{*}$ & 12.11 & $2.73 \mathrm{~ns}$ \\
\hline Error & 0.02 & & 0.07 & & 2.08 & & 4.44 \\
\hline
\end{tabular}

vine length, stem girth and the leaf area while the two passes of moldboard plow $\left(1.5 \mathrm{~g} / \mathrm{cm}^{3}\right)$ tillage method observed significant ( $p \leq 0.05)$ effects on leaf area only, but statistically ( $p \leq 0.05)$ the same with one pass of moldboard plow $\left(1.3 \mathrm{~g} / \mathrm{cm}^{3}\right)$ tillage method.

This study, therefore, concluded that for a tillage method (one pass of moldboard plow) at $11.5 \%, 1.3 \mathrm{~g} / \mathrm{cm} 3$ moisture content and bulk density respectively, the growth of watermelon could be enhanced in the derived savannah of Southwest zone of Nigeria as it improved the vine length, stem girth and number of leaves.

\section{Authors' Contributions}

K. M Babatunde carried out the field study, soiland crop growth analysis, and statistical analysis and draft the manuscript. J. D Oyedele conceived the study, participated in itsdesign and coordination. K. A Shittu participated in the design of the study, performed statistical analysis and O.A Adekanmbi helped draft the manuscript. All authors read and approved the final manuscript.

\section{References}

1. Okunlola A, Adejoro SA, Fakanlu G. Evaluation of Some Manure Types for the Growth and Yield of Watermelon in Southwestern Nigeria. Researcher. 2011;3(3):61- 66

2. Dauda SN, Ajayi FA, Ndor V. Growth and yield of water melon (Citrullus lanatus) as affected by poultry manure application. J. Agri. Soc. Sci. 2008;4:121-124.

3. Schippers RR. African indigenous vegetables: an over view of the cultivated species. Revised edition on CDROM. National Resources International limited, Aylesford, Chatthan, UK., N.R/ACO. EU. 2000;5660.

4. Enujeke EC. An assessment of some growth and yield indices of six varieties of watermelon (Citrulus Lanatus Thumb) in Asaba area of Delta State, Nigeria .Int. Res. J. Agric. Sci. Soil Sci.2013;3(11):376-382

5. Department of Agriculture, Forestry and Fisheries Republic of South Africa. Production guidelines. Watermelon (Citrullus lanatus). 2011.

6. Adesina JM, Sanni KO, Afolabi LA, Eleduma AF. Effect of Variable Rate of Poultry Manure on the Growth and Yield of Pepper (Capsicum annum) in South Western Nigeria. Academ Arena. 2014;6(1):9-13.

7. Yesim E, Yuksel AN .Yield response of watermelon to irrigation shortage. Sci. Hor. 2003;98(4):365-383.

8. Fehér T . Watermelon: Citrullus lanatus (Thunb.) Matsum.\& Nakai. In: Kalloo G \& Bergh BO (eds) Improvement of Vegetable Crops Pergamon Press, Oxford U.K. 1993;295-311.

9. Adeoye GO, Sridhar MKC, Adeoluwa 00, Oyekunle M, Makinde EA, Olowoake AA. (2008). Comparative evaluation of organo-mineral fertilizer (OMF) and mineral fertilizer (NPK) on yield and quality of maize (Zea mays (L)) Moench. Nigerian Journal of Soil Science , 18, 141-147.
10.Oguntola S. Watermelon; Hidden gem yet to be discovered. Nigerian Tribune. 2006.

11.Keshavarzpour F, Rashidi M. Effect of different tillage methods on soil physical properties and crop yield of watermelon (Citrullus vulgaris). World Appl. Sci. J. 2008;3:359-364.

12.Khurshid K, Iqbal M, Arif MS, Nawaz A. Effect of tillage and mulch on soil physical properties and growth of maize. Int. J. Agric. Biol.2006;8:593596.

13.Rashidi M, Keshavarzpour F. Effect of different tillage methods on soil physical properties and crop yield of watermelon (Citrullus vulgaris). ARPN Journal of Agricultural and Biological Science. 2007;2(6):1-6.

14.Lal, R. Tillage effects on soil degradation, soil resilience, soil quality and sustainability. Soil and Tillage Res. 1993;27(1-4): 61-70.

15.Takim FO, Fadayomi O. Influence of Tillage and Cropping Systems on Field Emergence and Growth of Weeds and Yield of Maize (Zea mays L.) and Cowpea (Vigna unguiculata L.). Australian Journal of Agricultural Engineering. 2010;1(4):141-148.

16.Anderson RL. No till proso millet production. Agron. J.1990;82:577580.

17.Oklahoma Cooperative Extension Service HLA 6236.Department of Agriculture, Oklahoma State University, Stillwater, Oklahoma. Watermelon production. 2015;1-4.

18.Bouyoucous GH. Hydrometer Method Improved for Making Particle Size Analysis of Soils. Agronomy Journal. 1962;54:464-465.

19.Gee GW, Or BD. Particle size analysis. In: J. H. dane and G. C. Topp (eds). Methods of soil analysis part 4.2002;255-293.

20.Walkley A, Black IA. An examination of the degtjareff method for determining soil organic matter, and a proposed modification of the chromic acid titration method. Soil Science.1934;37(1):29-38.

21.Bremner JM. Total Nitrogen. In: Sparks, D.L., Ed., Methods of Soil Analysis, Part 3, Chemical Methods, SSSA and ASA, Madison. 1996;11231184.

22.Sparks DL. (ed). Methods of Soil Analysis: chemical methods. Part 3. Soil Sci. Soc. Am. Book Series No. 5. ASA-SSSA. 1996;869-920.

23.Udo B,Utip U, Kufre EI, Monday T, Iduggafa MA. Fertility assessement of some inland depression and floodplain (wetland) soils in Akwa Ibom State. J Trop Agri Food Environ Exten. 2009;8(1):14-19.

24.Erbach D. Farm equipment and soil compaction. SAE Technical Paper Series,1986;8.

25.Barzegar AR, Asoodar MA, Khadish A, Hashemi AM, Herbert SJ. Soil physical characteristic and chickpea yield response to tillage treatments. Soil Tillage Res. 2003;71(1):49-57.

26.Osunbitan JA, Oyedele DJ, Adekalu KO. Tillage effects on bulk density, hydraulic conductivity and strength of a loamy sandy soil in southwestern Nigeria. Soil Till Res. 2005;82(1):57-64. 
27.Hammad EA, Dawelbeit MI. Effect of tillage and field condition on soil physical properties, cane and sugar yields in vertisols of Kenana Sugar Estate, Sudan. Soil Tillage Res. 2001;62(3-4):101-109.

28.0laoye J0. Influence of tillage on crop residue cover, soil properties and yield components of cowpea in derived savannah zones of Nigeria. Soil Tillage Res. 2002;64:179-187.

29.Babatunde KM, Adekanmbi OA, Adeyolanu AS, Salau MA. Effects of Varying Tillage Passes and 15-15-15 NPK Fertilizer on Some Agronomic Parameters, Nitrogen, Phosphorous and Potassium Uptake by Amaranthus viridis in Derived Savannah of Southwest Nigeria. J Horticulture. 2016;3:179.

30.Azim Zadeh SM, Koochakie A, Pala M. (2002). Effect of different tillage methods on soil bulk density, soil porosity, soil moisture content and yield of wheat under dry land condition . Iranian J. Crop Science, 4, (3) 218-233.
31.Mahboubi AA, Lal R, Favsey NR. Twenty-eight years of tillage effect on two soils in Ohio. Soil Science. 1991;57:506-512.

32.Shittu KA, Oyedele DJ, Babatunde KM. The effects of moisture content at tillage on soil strength in maize production. Egyptian Journal of Basic and Applied Sciences. 2017;4(2):139-142.

33.Kahlon MS. Soil Physical Characteristics and Crop Productivity as Affected by Tillage in Rice-Wheat System. Journal of Agricultural Science. 2014;6(12):107-114.

34.Khosravi MJ, Asoodar MA, Jamshidi AR. Effect of conservation tillage and remains under the influence of drip irrigation on watermelon yield in the Bardsir Region, Intl J Farm \& Alli Sci.2013;2(13):363-370.

35.Zeliha B, Akbolat D. Evaluation of conventional and conservation tillage system for maize. Agronam. J. 2005;4(2):122-126. 